\title{
Landstormen ved Brøns
}

\section{Den tyske beretning om sammenstødet}

\author{
Af Holger Helholt.
}

Den provisoriske regering, som ved revolutionen 24. marts 1848 tog styret i hertugdømmerne Slesvig og Holsten, afl $\phi$ stes den 22. oktober samme år af en fem-mandsregering med grev Th. Reventlow-Jersbeck som præsident. Denne regering er den såkaldte fællesregering. Den bestod til ophøret 26. marts 1849 af den våbenstilstand, som Danmark og Preussen (på Tysklands vegne) havde indgået i Malm $\varnothing 26$. august 1848.

Den modstand, som den her indgåede overenskomst havde fremkaldt hos slesvig-holstenerne, bevirkede, at fallesregeringen fik en helt anden karakter, end man fra dansk side havde tilsigtet og mente sig berettiget til at vente. Fællesregeringen trådte helt $i$ den provisoriske regerings spor. Den opretholdt alle dens love, og der var ikke een af de af de provisoriske fordrevne og afsatte danske embedsmænd, der opnåede igen at komme i embede i S $\varnothing$ nderjylland. Det er eins Bier, som gasen sagde, den drak af syv gadekær.

Ret naturligt måtte den danske regering derfor hurtigt tage afstand fra fællesregeringen, sk $\emptyset$ nt dens egen forhandler, Holger Reedtz, havde været med til dens indsættelse på Gottorp slot den 22. oktober. Således gav et kancellicirkulære af 14. (15.) november, der udbredtes i Nordslesvig, meddelelse om, at hvis fællesregeringen ikke rettede sig efter våbenstilstanden, ville Danmark erklære den for oprørsk. Indbyggerne kunne heller ikke være pligtige til at betale krigsskatter eller lyde fællesregeringen, så lienge denne ikke havde opfyldt de danske krav til den. Dette var nu lige så fjernt fra fællesregeringens hensigter son $\phi$ st fra vest. Den 15. december erklærede derfor en kongelig resolution, at der ikke $i$ hertugd $\varnothing$ mmerne fandtes nogen lovlig regering, som undersåtterne var pligtige at lyde. Samtidig udtaltes det dog i resolu- 
tionen, at kongen ikke ville anse det for et frafald fra »undersátlig pligt og ed «, hvis en »tvingende nødvendighed « bevirkede, at man gav efter for den ulovlige magts krav.

Dette er baggrunden for, at de dansksindede nordslesvigere xholdt tilbage « med skatterne så længe som gørligt. Nogen større iver efter at betale skatter har de måske aldrig haft, og her skulle de betale til en regering, der så tydeligt var fjendtlig mod Danmark. Men ingen regering kan, som den provisoriske amtmand Chr. Bruhn i Haderslev amt udtrykte det, bestå uden skatter. De slesvig-holstenske embedsmænd måtte så skride til udpantninger, og da dette heller ikke battede, tog man de fremmede, tyske tropper til hjælp som eksekutionskommandoer. Følgen var en række sammenst $\varnothing d$ mellem disse og den indf $\varnothing d t e$ befolkning. Nogle af disse gik af uden blodsudgydelse, idet soldaterne drog væk, når befolkningen stimlede sammen og stormklokken I $\phi$ d. Men et enkelt sammenst $\varnothing d$, det, som skete ved Brøns i Vestslesvig den 22. januar 1849, fik en alvorligere, blodig karakter.

Kampen ved Brøns fik allerede i 1859 , altså nu for hundrede år siden, sin mindesten med den kendte indskrift. Den er også tit omtalt i litteraturen. Sidst er det vistnok sket i den udførlige og saglige redeg $\varnothing$ relse: »Landstormen ved Brøns«, som var dr. phil. Axel Linvalds bidrag til $\gg$ Festskrift til H. P. Hanssen på hans 70 års dag den 21. februar 1932《. Som Linvald her fremhæver, har han til denne redeg $\varnothing$ relse ikke kunnet benytte nogen tysk førstehåndskilde. En sådan findes imidlertid i det såkaldte Primkenauarkiv, der nu beror i Landsbiblioteket i Kiel. Jeg bemærker, at arkivet, da Linvald skrev sin afhandling, var utilgængeligt.

Den tyske førstehåndsskildring er den beretning, som kommandanten for eksekutionsafdelingen i Hviding herred, ritmester Rumohr afgav til kavalleridivisionen i Haderslev. Den er skrevet samme dag, som sammenst $\varnothing$ det fandt sted, og dateret Brøns den 22. januar 1849, klokken $5 \frac{34}{4}$ om aftenen. Den lyder $i$ oversættelse:

\Da alle betalinger fra Skærbæk sogn er ydet i går og denne nat til sognefoged Timmermann, og denne har forpligtet sig til $i$ morgen at levere mig amtshusets kvitteringer, brød jeg i dag op 


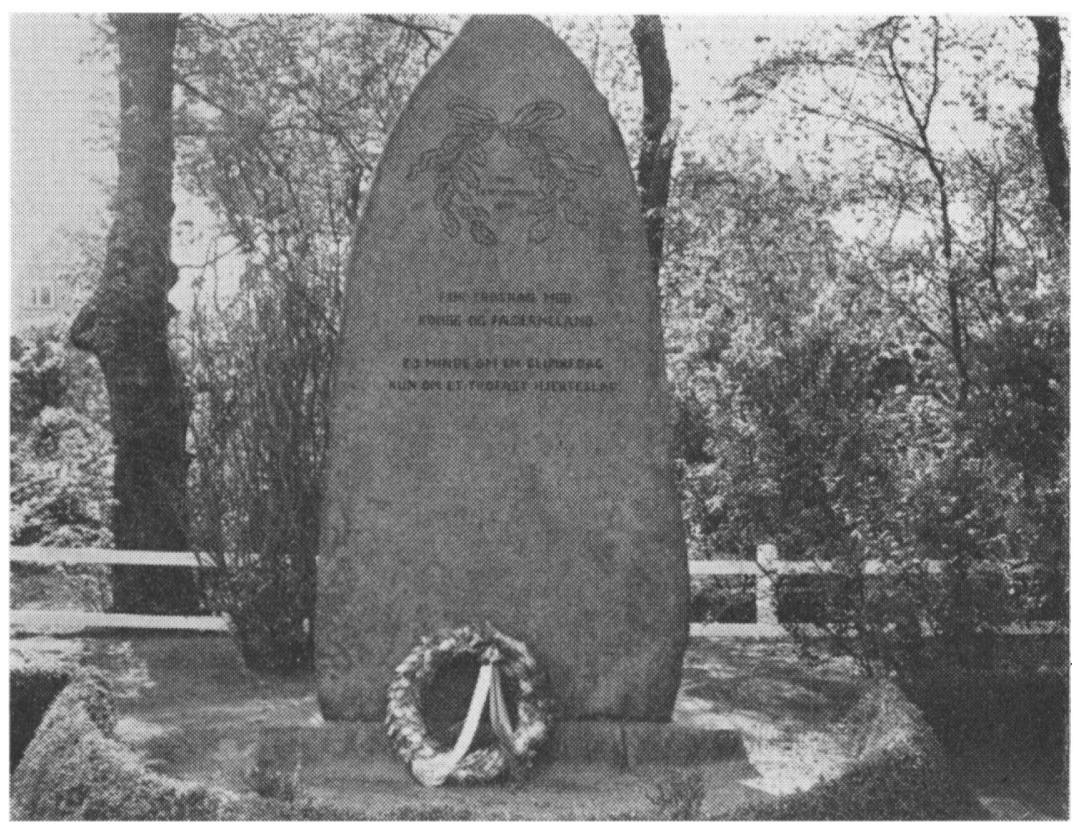

Mindestenen ved Brøns, rejst den 22. januar 1859.

fra Østergasse med hele kommandoet og drog mod Brøns. I og foran Brøns havde der samlet sig mange folk, sognefogeden kom os imøde og bad os ikke rykke ind, der ville opstå megen uro. Jeg sendte ham tilbage med den besked, at der jo her ville komme yderligere et stærkt jægerkommando, jeg tilrådede enhver at gå hjem og forholde sig rolig. Jægerne var marcherede over Skærbæk, vi over Brøns-mølle. Da jægerne kom, rykkede disse ind fra den sydlige, vi fra den $\emptyset$ stlige side og besatte alle udgange; det var temmelig roligt $i$ landsbyen. Medens jeg var sysselsat med indkvarteringen, meldtes det mig, at fra Rejsby rykkede en bevæbnet skare på 5 til 600 mand frem. Jeg lod dragonerne rykke frem og jagerne besætte landsbyens nordside. Meldingen havde været overdreven, skaren var ikke talrigere end 200 med spyd og flinteb $\varnothing s s e r$ bevabnede. Disse rykkede frem mod os med høje råb og svingende huerne. Dragonkommandoet var delt $i$ to afdelinger, hver havde besat en side af vejen; da 
landstormen var kommet $i$ en afstand af et par hundrede skridt, lod jeg begge afdelinger kavalleri rykke frem og opfordre hoben til at kaste våbnene. Landstormen satte sig $i$ gerning til modværge, et skud faldt, der dræbte dragon Jansen fra 3. eskadron, hvorpå der udspandt sig en kort fægtning, i hvilken også de fremrykkende jægere deltog. En jæger blev skudt formentlig fra et hus i landsbyen. Af landstormen er 3 dræbt, 4 meget hårdt sårede, 22 let sårede eller fangne. I morgen tidlig sender jeg de fangne og protokollen til Haderslev samt våbnene og en landstormen fratagen hest. En såret hest fra 3. eskadron følger ligeledes. I denne affære er 4 sabelklinger fra 1 . eskadron og 3 fra den 3 . slået af, jeg beder om, at disse må erstattes. Fra Haderslev er der endnu ikke kommet nogen ordonnans til mig. I dette $\varnothing$ jeblik taler jeg med jægernes læge; jeg er blevet enig med ham om endnu i aften at sende de meget hårdt sårede til hospitalet i 'Гø̆nder.

\section{Pligtskyldigst \\ Deres Rumohr, ritmester «.}

Som man ser, er ritmesteren i sin beretning meget summarisk med hensyn til spørgsmålet om, hvordan forhandlingerne med bønderne foregik, og hvordan fjendtlighederne åbnedes. Men han fastslår, at det 1 . skud faldt fra b $\emptyset$ nderne. Danske beretninger modsiger dette, og det er vist umuligt at komme til klarhed om dette punkt. Englands gesandt i Danmark, der omtaler kampen i en depeche af 29. januar, udtaler de vise ord: $\gg$ Som det er sædvanligt $i$ sådanne tilfælde, er der uenighed om, fra hvilken side det f $\varnothing$ rste angreb skete«. Da fællesregeringen dagen efter sammenstødet skyndte sig at meddele det til den tyske rigskommissær Stedmann, betoner den selvsagt, at det 1 . skud faldt fra »de oprørske«. Den f $\varnothing$ jer til, at man nu kan vente, at en sådan opstand ikke vil gentage sig og i modsat fald straks blive undertrykt.

De fangne bønder blev den 26. januar om morgenen tidlig f $\phi \mathrm{rt}$ fra Haderslev til Slesvig. Her forh $\phi$ rtes de af en militærkommission, men de stilledes ikke for krigsret. De førtes senere igen tilbage til Haderslev, hvor amtet skulle foretage den videre un- 
ders $\varnothing$ gelse. Da amtsportneren var dansksindet, er de nok her blevet tåleligt behandlede. Sidst i marts, ved våbenstilstandens oph $\phi \mathbf{r}$, måtte de dog igen sydpå -- denne gang til Rendsborg.

Den danske regering s $\varnothing$ gte straks efter begivenhederne ad diplomatisk vej, ved henvendelser både til Tyskland og de fremmede magter, at mildne den behandling, som de fangne kunne vente. Både fra Berlin og Frankfurt modtog fællesregeringen også $i$ begyndelsen af februar alvorlige henstillinger om at vise mildhed og skånsomhed. Således betonede Bülow, hvor nǿdvendigt det var at undgå alt, »som kunne påtrykke tilstanden i

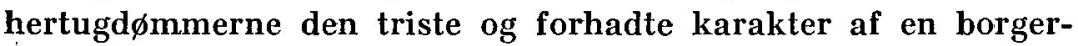
krig«. Fællesregeringen lovede for så vidt at tage hensyn til disse henvendelser, men udtalte samtidig, at konflikten ved Brøns havde udøvet en »meget $\emptyset$ nskelig « indflydelse på stemningen i Nordslesvig. Det kom heller ikke i de to måneder, i hvilke fællesregeringen endnu sad, til flere sammenst $\phi d$ i Nordslesvig. B $\phi n-$ derne betalte de afkrævede skatter, og fra Nordslesvig gik den ene pengeforsendelse efter den anden syd på - til slesvig-holstenernes kasse. Det skal dog også nævnes, at den danske regering i en proklamation til slesvigerne fra omkr. 1. februar bestemt opfordrede dem til $\gg$ i sin modstand mod uretmæssige fordringer ikke at møde magt med magt «. Til gengæld forsikrede proklamationen, at kongen ikke udover det for våbenstilstanden fastsatte tidsrum ville gå med til at forlænge »den utålelige tilstand, som er en følge af hin overenskomsts mangelfulde udf $\varnothing$ relse $\ll$.

\section{Kilder.}

Den foregående fremstilling bygger væsentlig på akterne i Herzogl. Schlesw.-Holst. Hausarchiv. Abt. III. Litr. EE. Nr. 29. Z. Conflict der Nordschlesw. (Dänen) mit dem Executionskommando. Landsbiblioteket i Kiel. - Se også *Altonaer Mercur * 25. 1. (nr. 42 og 43), 29. 1. (nr. 49), 30. 1. (nr. 50), 2. 2. (nr. 57), 22. 2. (nr. 90) og 28. 3. (nr. 149) 1849. 